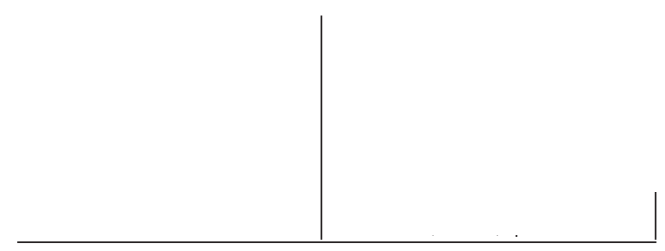

Rev. Latinoam. Psicopat. Fund., IX, 2, 339-361

\title{
De médico e louco... as fronteiras entre discursos
}

Nádia Maria Weber Santos

Este artigo apresenta aspectos de dois "discursos", concernentes à sensibilidade sobre a loucura, em representações (narrativas) escritas por um médico e um paciente, ambos do Hospital Psiquiátrico São Pedro de Porto Alegre, inseridos nos anos 20 a 50 do século XX, no Rio Grande do Sul. Para isto, utilizou-se o livro de Jacintho Godoy, A Psiquiatria no Rio Grande do Sul, publicado pelo autor em 1955, e as cartas de um paciente interno, em 1937, arquivadas em seu prontuário médico.

Palavras-chave: Loucura, psiquiatria, história cultural, Rio Grande do Sul, narrativa 


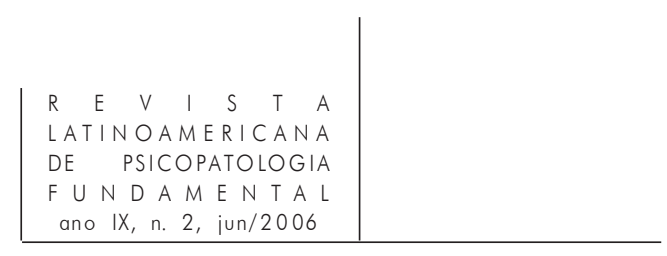

Minha inquietação como psiquiatra e minhas preocupações pelo aspecto histórico do fenômeno social da loucura levaram-me a seguir as trilhas dos historiadores. Há vinte anos debruço-me diariamente sobre a árdua tarefa de tratar indivíduos acometidos de transtornos mentais e seus sofrimentos psicológicos. E há pouco mais de oito anos, dedico-me a percorrer uma "trajetória histórica" que inclui a busca de pistas e indícios que mostrem como a sociedade gaúcha representou e imaginou seus "loucos" no correr do tempo. ${ }^{1}$

Sem dúvida, estas preocupações possuem um ponto de partida, ou talvez vários, porém o mais importante é que elas têm a ver com uma visão de mundo que me acompanha desde cedo: o horror às injustiças, o horror à exclusão social. Visão de mundo, ou a complexa noção Weltanschauung dos alemães é algo que "vem conosco" e que ao mesmo tempo construímos durante a vida, com nossa experiência no mundo, com os fatos e com as pessoas.

Pois bem. Algumas primeiras experiências que tive em clínicas psiquiátricas em Porto Alegre, como estudante-estagiária, foram definitivas para eu repensar as práticas psiquiátricas e cogitar outras formas de lidar com a loucura. Resumidamente as exponho neste parágrafo: chocou-me o fato de, no primeiro dia de estágio da faculdade, com apenas 17 anos, presenciar uma sessão de ECT, e, ainda por cima, em um amigo meu do bairro em que morava. No mesmo estágio, passei por uma outra experiência, oposta a esta: eu e minhas colegas de estágio conhecemos um paciente na unidade masculina, que vivia proferindo "palavras divinas", nu em cima das mesas, agressivo quando algum atendente chegava perto, do qual ninguém chegava perto. Nós, como estagiárias, tentávamos nos aproximar para conversar e compreender seus delírios e, em pouco tempo, sem tocar um dedo em nenhuma de nós, ele foi receptivo, começou a nos responder e conversar, estando, em uma semana, fora de seus delírios e integrado com os outros pacientes na "roda de chimarrão". "Graças à compreensão humana", pensava eu. Anos mais tarde, em outro estágio, uma paciente, internada em hospital psiquiátrico, certo dia disse: "Mas são loucas as

1. Este percurso levou-me a realizar o mestrado em História pelo PPG de História da UFRGS (2000) e posteriormente o doutorado na mesma instituição, resultando nas pesquisas apresentadas em Santos (2005c) e Santos (2005b), respectivamente, ambas sobre a temática da história da psiquiatria e da loucura no RGS e no Brasil. 


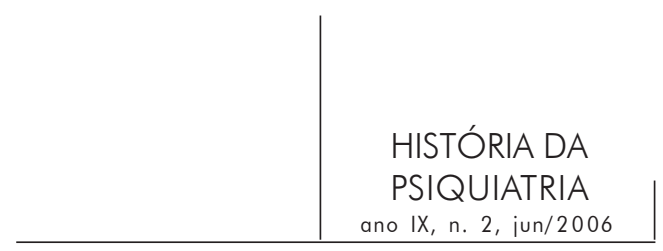

falas dos médicos! Eles dizem palavras, coisas que ninguém entende. Quem entende? Nós pacientes falamos loucuras por que somos loucos, mas eles dizem loucuras e besteiras”.

A extensa e profícua historiografia sobre a história da psiquiatria no Brasil, e especialmente no Rio Grande do Sul, a partir dos discursos dos vários profissionais que se debruçam sobre o campo da história da saúde e da doença, provenientes de distintos "lugares” do saber, privilegia o aspecto social e muitas vezes “macro-estrutural” dos processos históricos, deixando de considerar outros pontos de vista. ${ }^{2}$ Não revela alguns pormenores que eu gostaria de contemplar neste artigo. Não diz explicitamente, por exemplo, da "história desde baixo”, como referem alguns historiadores, isto é, a história daqueles que foram favorecidos (ou desfavorecidos) pelos tratamentos, os reais usuários do complexo sistema de saúde paulatinamente instaurado, ou mesmo certas peculiaridades regionais.

Gostaria, assim, de fazer um recorte abrangendo dois pontos de vista, ambos inseridos nos primeiros quarenta anos do século XX no Brasil e que complementam algumas noções já exaustivamente discutidas e dialogam com os autores e textos mais conhecidos sobre o assunto. Um deles é aquele referente à instituição psiquiátrica no Rio Grande do Sul, exemplificado pelo paradigmático Hospital Psiquiátrico São Pedro de Porto Alegre (HPSP) e o “discurso” de um de seus mais polêmicos diretores, Jacintho Godoy, a partir de seu próprio livro, já mencionado. $\mathrm{O}$ outro ponto de vista refere-se, em contrapartida, àqueles dos próprios doentes, ou "loucos”, desde o “micro-espaço” de sua doença. Recupero, assim, as representações e sensibilidades desses acerca da doença mental e do meio que os abriga, mostrando a partir da escrita registrada dentro de uma internação manicomial por um paciente do HPSP de Porto Alegre, em 1937, 3 através do olhar de quem sofria os cuidados (e descuidos) desta medicina e desta sociedade. Avalio que os discursos e reflexões dos pacientes foram esquecidos na maioria dos debates e textos historiográficos e acho importantíssimo recolocar/ reconduzir esta questão. É profícuo, inclusive, fazer o cotejo dos discursos do médico e do paciente, mesmo que brevemente, a fim de observarmos que se em poucos momentos eles interagem, em outros se afastam radicalmente. Assim, uma outra versão da história pode ser contada...

2. Para esta discussão ver Santos (2005b). Fazendo parte das raras exceções é a tese de doutoramento de Wadi (2002a), que trabalha com a história de uma paciente internada no Hospício São Pedro de Porto Alegre, de 1909.

3. Este paciente será chamado de TR e descobriremos um pouco de sua história de vida ao longo deste artigo, que culminará na apresentação integral de uma de suas missivas redigidas nesta internação de 1937 (Carta 11 - Meditações e previsões sobre o futuro). Maiores detalhes deste caso, ver Santos (2005c). 


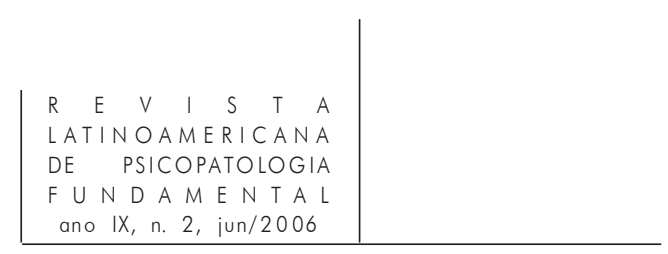

A institucionalização da loucura e da Psiquiatria no Rio Grande do Sul, tanto quanto no restante do país, passou por um longo processo de lutas, contando com rupturas entre as práticas estabelecidas e aquelas introduzidas pela disciplina e seus peritos - os psiquiatras (Wadi, 2002). Concordo com Wadi, quando diz que o século XIX trouxe à tona novas sensibilidades sobre a loucura, tendo sua internação tomado uma nova forma, pois o paciente tido como louco foi separado dos demais desajustados sociais e um lugar especial para sua guarda foi requerido, surgindo então o hospício, "como uma necessidade de uma época histórica, ligadas a outras transformações no período” (ibid., p. 25).

Mesmo existindo semelhanças nos processos, diferenças importantes marcaram a luta para a construção do saber/poder médico sobre a loucura e a construção desse locus específico: aqui no Rio Grande do Sul, diferentemente do Rio de Janeiro, o hospício - separado da Santa Casa de Misericórdia - não foi criado a partir de um movimento lançado por médicos e pela medicina. Se, no Rio de Janeiro, a Sociedade de Medicina tomou frente na luta pela criação do hospício, já no estado do Sul, no início da década de 1870, não existia nenhuma organização médica que tomasse frente às lutas desses. "Os médicos formados atuando na Província eram poucos na época, assim como eram poucos também os que atuavam na Santa Casa” (ibid., p. 28).

Citando ainda Yonissa Wadi - a primeira historiadora gaúcha a debruçar-se profundamente sobre a história, desde seu início, em meados do século XIX, da institucionalização da loucura e da psiquiatria em nosso Estado, a partir de sua pesquisa acadêmica de mestrado - em momento algum, nos primórdios dessa luta que leva à criação do Hospício Psiquiátrico São Pedro de Porto Alegre (fundado efetivamente em 1884), percebe-se a presença dos médicos como protagonistas da iniciativa. Considerando os registros históricos, como ela relata, só é possível colocá-los "em papéis coadjuvantes naquele momento, ainda que muitos dos argumentos da crítica construída pela medicina social nascente estivessem presentes na argumentação dos provedores da Santa Casa de Misericórdia de Porto Alegre” (ibid., p. 28).

Com o apoio dos dirigentes da Santa Casa, foi ao provedor desta instituição assistencial que coube a iniciativa de sugerir a criação de um local para enviar os pacientes “alienados mentais", separando-os, portanto, daqueles internados no hospital da Misericórdia.

O movimento deflagrado pelos protestos do então provedor, José Antônio Coelho Junior, em 1873, apoiava-se em três argumentos principais: 1) péssimas condições em que viviam, no Asilo da Santa Casa, os alienados enviados para a capital de todos os pontos da Província, sem que se pudesse minorar seus sofrimentos; 2) a confusão existente entre alienados e criminosos, fazendo com que ocupassem os mesmos lugares de reclusão, ou seja, a Cadeia Pública, por 


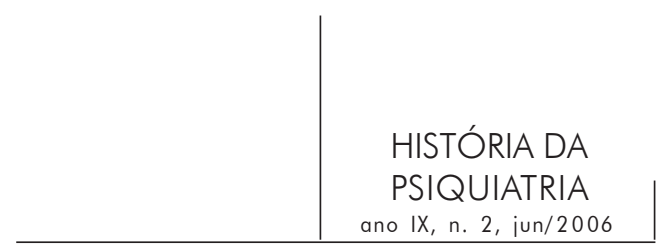

não existirem lugares suficientes no Hospital de Misericórdia para receber os primeiros; 3) a responsabilidade da sociedade cristã e civilizada que não devia fechar seus olhos para tais problemas (ibid., p. 28).

Contudo, ainda seguindo a trilha deixada por essa historiadora pioneira, foi o saber médico, ocupando o papel principal ou sendo mero coadjuvante, “o grande responsável pela efetivação do Hospício: seu reconhecimento social como espaço fundamental para a guarda dos loucos, em primeiro lugar, e para seu tratamento e cura, quando ocupado e transformado pelas práticas médicas” (ibid., p. 29; grifo meu).

Dando um salto no tempo, indo para a década de 20 do século XX, tem início o que denominei “a era Godoy” no HPSP, referindo-me ao médico Jacintho Godoy Gomes (conhecido, entre todos nós do Rio Grande do Sul, como Jacintho Godoy).

Não foi simples o processo de construção da “autoridade médica” nessa instituição, nem no âmbito científico, menos ainda no institucional. Mas esse "poder” do médico instalou-se, em definitivo, a partir das duas gestões do doutor Jacintho Godoy (JG), que aconteceram nos anos de 1926-1932 e 1937-1950, respectivamente sob a égide do positivismo borgista (Borges de Medeiros) e do autoritarismo de Getúlio Vargas.

Formado pela Faculdade de Medicina de Porto Alegre em 1911, e tendo realizado um estágio junto a eminentes psiquiatras e neurologistas franceses da Salpêtrière de Paris por dois anos (1919-21), JG foi não somente o diretor do HPSP nessas duas gestões, como também o idealizador e primeiro diretor do Manicômio Judiciário e da Diretoria de Assistência a Alienados do Rio Grande do Sul.

A primeira gestão do doutor Godoy frente ao Hospital São Pedro - fundado em 1884 - operou um deslocamento no discurso e na prática alienista no Rio Grande do Sul, indicando a passagem de uma psiquiatria marcada pelo ecletismo terapêutico para os domínios do organicismo. Personagem polêmico foi Godoy, um mestre-escola que se autoconstruiu - e a própria figura do psiquiatra por ele representada - como um filantropo, um membro de corporação e um homem de ciência, posições que procurou marcar através de práticas discursivas variadas. Porém, Godoy foi mais do que isso, foi um homem de política ligado aos setores dirigentes sul-riograndenses de feição positivista. Sua trajetória frente à maior e mais representativa instituição psiquiátrica do Rio Grande do Sul, durante vinte anos, bem como as intempéries que sofreu no cargo - inclusive a que o levou a ser exonerado definitivamente daquele em 1951 - estão intimamente ligadas às mudanças no equilíbrio das relações políticas no Rio Grande do Sul e às práticas psiquiátricas de exclusão do doente exercidas no Estado (Wadi \& Santos, 2006). 


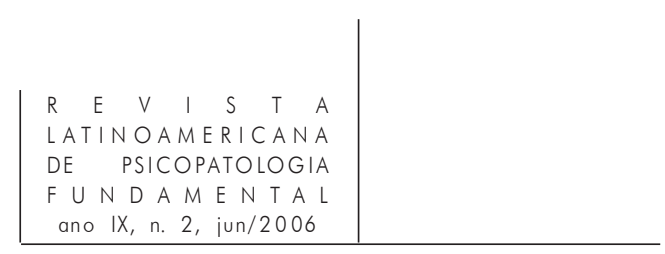

Esse psiquiatra porto-alegrense influenciou fortemente os estatutos, os regimentos e as práticas médicas do HPSP, em sua época e posteriores - embora o "corpo clínico" do hospício contasse com um grande número de médicos e psiquiatras eminentes na cidade, como os doutores Dyonélio Machado e Luís Ciulla, muitas vezes críticos de Jacintho. Está, possivelmente também nessa influência, grande parte da base da psiquiatria do Rio Grande do Sul, tendo sido o HPSP paradigmático em nosso Estado, em relação ao tratamento de doenças mentais e, por que não dizer, das práticas de exclusão social exercidas sobre tais enfermos.

Em 1937, ano em que o paciente TR foi internado no HPSP, começava a segunda gestão desse eminente médico gaúcho. E foi a partir desse ano que o fenômeno da superlotação de pacientes, que já era apontado em gestões anteriores, ficou mais grave.

Mas vejamos um pouco de Jacintho por ele mesmo, suas falas, seus escritos. Seu livro, escrito após sua exoneração definitiva do hospital em março de 1951, e publicado em 1955, chamado A psiquiatria no Rio Grande do Sul, embora com este título, versa sobre a história do Hospital São Pedro desde que o autor assumiu sua direção. O período que o antecede, da fundação em 1884 até 1926 (42 anos), mereceu pouca atenção, de apenas meia página, no início do primeiro capítulo intitulado "As obras de remodelação do velho hospício".

A análise desta obra coloca-nos frente a algumas reflexões de cunho histórico, advindas pela própria narrativa do autor. Ao mesmo tempo em que JG tenta legitimar a posição do médico e do "psiquiatra perito" na construção do saber sobre o objeto "loucura", ele também se outorga o poder de renovar, remodelar, modernizar o hospício da cidade.

Seu livro, que poderia ser apenas um livro de memórias, tornou-se um verdadeiro documento histórico no que tange as grandes obras realizadas no hospital durante sua "era", mas também uma "auto-exaltação" de si mesmo e destas suas "magníficas obras" no HPSP. "Esta história da psiquiatria no Rio Grande do Sul precisava ser escrita. Coube-me esta tarefa por estar vinculada à outra história, a do Hospício São Pedro, desta cidade, em cuja vida se entrosou mais de vinte anos de minha carreira profissional, precisamente na sua fase de transformação de depósito de alienados em hospital psiquiátrico” (Godoy, 1955, p. 15).

Nele, JG relata e descreve, além das obras concretas, as visitas dos ilustres políticos e sanitaristas, a repercussão na imprensa (com transcrições extensas de reportagens positivas à sua obra), as técnicas médicas introduzidas, os serviços mentais prestados à comunidade, preconizados por ele, seus discursos proferidos em ocasiões diversas (como nos almoços dados em sua homenagem e a dos visitantes, ou em inaugurações de alas ou do Manicômio Judiciário etc.), prestação de contas em relatórios, reportagens de rádio, homenagens recebidas, 


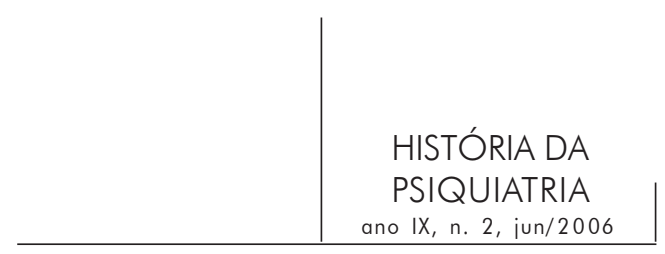

muitas fotos do hospital e seus funcionários e médicos e até plantas arquitetônicas de suas modificações da estrutura dos prédios.

Torna-se, assim, também uma obra riquíssima para observar a personalidade desse homem que se construiu como psiquiatra filantropo, como homem de ciência e como aquele que modernizou a psiquiatria no Rio Grande do Sul. Porém, na pesquisa histórica realizada (Santos, 2005c) cotejou-se o discurso de JG com outros documentos, como relatórios do hospital, reportagens da época e até mesmo com relatos de casos dos prontuários médicos e depoimentos de pacientes. Desta forma, adquiriu-se um "perfil histórico" mais completo desse médico eminente de nosso meio.

JG foi demitido do cargo de diretor do HPSP duas vezes, sendo acusado de favorecimento político, em 1932, e má administração em 1950, tendo deixado em definitivo a direção do hospital em março de 1951. Em 1944, JG sofreu um processo administrativo impetrado por acusações referentes à sua administração, feitas por um médico do hospital, que na ocasião fez severas críticas ao diretor do HPSP, relativas aos tratos a um paciente seu e também às instalações do hospital. Coincidentemente, foi também em 1944 que JG introduziu no HPSP a técnica "terapêutica" do eletrochoque.

Em 1932, segundo ele mesmo, foi “a circunstância de uma velha ligação de amizade com um grande homem público que se viu envolvido, na ocasião, no movimento armado pela reconstitucionalização do país”, a responsável por sua saída do cargo. Sabe-se que JG era amigo pessoal de Borges de Medeiros, de quem havia sido secretário particular, no PRR (Partido Republicano Riograndense), em torno de 1910, com 25 anos de idade. Na época, a Revolução Constitucionalista dividiu a oligarquia gaúcha: Borges de Medeiros ficando na "ala" regionalista, de apoio aos paulistas, em oposição a Getúlio Vargas e, conseqüentemente, a Flores da Cunha, que como interventor no Rio Grande do Sul demitiu Jacintho Godoy da direção do HPSP.

Como ele mesmo refere em seu livro, foi no surgir do Estado Novo que, em dezembro de 1937, "reintegrado pelo ínclito e saudoso General Daltro Filho, retomei a faina da remodelação interrompida, agora preocupado, em primeiro lugar, em refazer o que se havia deteriorado" (Godoy, 1955, p. 16). Ele conheceu Getúlio Vargas em sua "juventude acadêmica”, aos 21 anos de idade, quando já cursava a Faculdade de Medicina, quando se associou a um "pugilo de acadêmicos que liderou uma campanha política, tornada famosa, na eleição presidencial de Carlos Barbosa” (ibid., p. 9).

Em discurso que proferiu quando de seu retorno, em 1937, ele disse:

Volto ao meu cargo já envelhecido, porém com a mesma flama acesa do trabalho de dez anos atrás; fiel cumpridor dos regulamentos, não distinguindo 


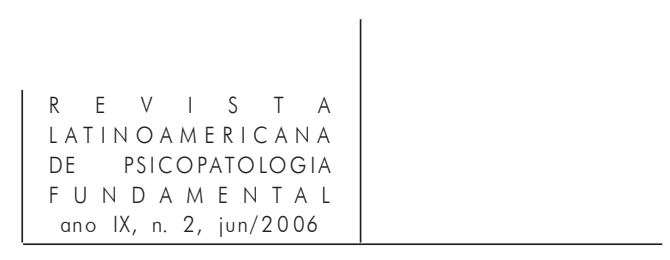

nos funcionários sob minha direção, os homens com as suas virtudes ou as suas falhas, mas iguais propulsoras da máquina administrativa e de quem tudo se deve exigir em prol dos doentes recolhidos a esta casa. A psiquiatria, por ter sido criação de um filantropo, tem ficado à margem da Medicina, nimbada de um halo de misticismo, dando origem aos mais absurdos preconceitos sobre as doenças mentais. Por isso, o diretor de uma casa de psicopatas tem uma missão tutelar sobre os entes humanos confiados à sua guarda. Da minha parte, nesta função, sou como certos reivindicadores a idéias prevalentes. A minha idéia prevalente é elevar o doente mental à dignidade de doente comum, suprimindo, com desvelos excepcionais e prodígios de assistência, o que não sabem pedir e nem podem reclamar os nossos irmãos inconscientes que soçobraram na treva da alienação. (ibid., p. 145-6).

JG iniciou a reforma do hospício já no início de sua primeira gestão, contando com dinheiro vindo do governo do Estado, “cerca de cinco milhões de cruzeiros, que o governo Borges de Medeiros resolveu, no ano de 1926, inverter em obras de remodelação do velho hospício de alienados ...” (ibid., p. 29). Incansável, JG presenteou o leitor de seu livro, no referido primeiro capítulo sobre as obras de remodelação, com o extenso relatório que prestou sobre as obras efetuadas, em 1927, ao então Secretário dos Negócios do Interior e Exterior, dr. Oswaldo Aranha, onde foi minucioso nos detalhes. Incluíam saneamento do hospital, canalização de água, remodelação da farmácia, laboratório, clausura das irmãs religiosas (“enfermeiras” de então), capela, alojamentos de doentes etc.

Não é exagero identificarmos no livro de Jacintho uma preocupação extrema em deixar registrado com tudo o que pôde, o fato de ter sido ele o grande modernizador do hospital. No segundo capítulo do livro, intitulado "Repercussão na imprensa local”, onde ele continua se referindo a essas obras de remodelação, sendo incansável em sua laudatória, chama a atenção o que um provável artigo (que não está identificado) coloca: “A obra que o dr. Jacintho Godoy vem realizando no antigo Hospital São Pedro é um trabalho que merece, por todos os títulos, ser devidamente conhecido e admirado” (ibid., p. 43). E na página seguinte, entre outros elogios, está: "Desapareceram, assim, quaisquer atitudes de violência com que torturavam aos alienados nas épocas recuadas, em que a força era o fator mais empregado para a cura. (...) É o mesmo, o espírito de ordem e eficiências que preside cada uma das demais dependências do estabelecimento" (p. 44).

É interessante esta afirmativa, se fizermos a comparação com a reportagem que originou sua exoneração em 1951, intitulada "Desleixo e desumanidade Mergulho nos abismos da mansão da loucura - Um inquérito que se torna necessário - Mergulho no abismo - Inenarrável sordidez - Promiscuidade - Uma grave acusação - problema de administração”, do Diário de Notícias (D.N.) de 


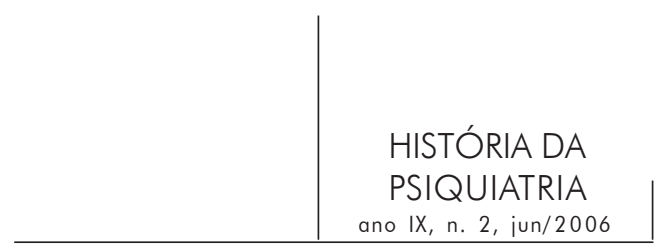

22 de março. O seguinte trecho, acompanhado de fotos, é um dos muitos que remete ao oposto do que JG colocou em seu livro:

Chegamos exatamente à hora da refeição, cerca de 11 horas. Num vasto galpão chamado refeitório, no silêncio sepulcral das fisionomias inexpressivas, sentavam-se comprimidos 760 doentes. Com o chão embarrado e umedecido, poças d'água aqui e acolá, abre-se o refeitório, exceto na parte sul, a todos os ventos. Sem janelas, sem portas, entram furioso vento e chuva, entisicando os miseráveis insuficientemente vestidos. Não é de estranhar, então, a incidência bruta da tuberculose entre eles. Mas o aspecto doloroso não pára aí: seus detalhes chocantes ferem sucessivamente e somam-se no estridente da nota de uma abjeção a que foram criminosamente atirados esses coitados de cuja sorte nenhum de nós está livre. São três funcionários para a todos atender. É a falta de talheres: não possuem uma colher sequer, comem com a mão, levam o prato à boca, brutalmente. É servido arroz e feijão, às vezes carne, e, como falta prato fundo de folha, deixam de tomar sopa. Aos que trabalham servem ração dupla. E acontece que por falta de funcionários e vigilantes os doentes mais fortes roubam o único pão aos incapazes de se defender, tirando-lhes também não raro a própria comida. Quem nos contou este detalhe foi uma irmã de caridade, cuja voz comovida traduzia um sentimento de infinito desamparo. (D.N., p. 12)

Mas mais chocante é a passagem seguinte da reportagem, intitulada “Inenarrável sordidez”, que levou a queixa de má administração ao diretor do manicômio:

A poucos passos do "refeitório", ergue-se o pavilhão dos fujões. Neles são trancafiados - como o nome indica - os doentes que se evadem do hospital, bem como os destruidores e depredadores. Nus, encaveirados, cabelos raspados, indefinível palidez, ensimesmados pelos cantos, empoleirados pelas camas tipo beliche, pesando um bafio insuportável a provocar vômitos incoercíveis. E enquanto um demente uivava e esmurrava a cabeça em "ais" lancinantes e ferozes que crispavam os nervos, um outro completamente despido tinha esparramado pela cama a comida e sobre ela sentava e calmamente almoçava. Aqui se mostra, mais uma vez, o desleixo da direção passada do São Pedro. Esses “fujões” e "destruidores" ficavam trancafiados no pavilhão, sem receber durante meses a fio um raio sequer de sol. Que custava levantar umas paredes ao lado, pequeno pátio - como está fazendo agora a atual direção - onde pudessem eles apanhar um pouco de sol? Bastaria para se ter esta inspiração um interesse mínimo ... (D.N., p. 12)

E, diametralmente oposto ao que consta no livro posterior de Jacintho, temos:

Saindo do grande pátio aos fundos do hospício, por pequena porta, passase para a seção dos "sórdidos". Foram os doentes que apelidaram o dormitório, 


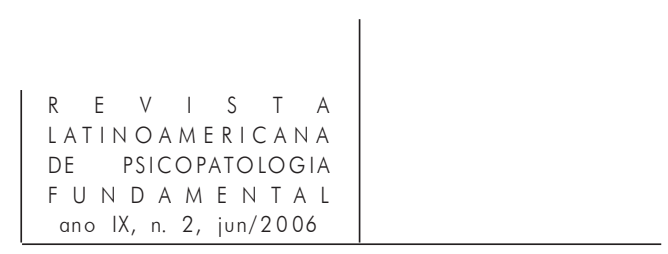

que aqui se encontra, de maloca. Em galpão escuro de quatro metros de largura por doze de comprimento, dormem trinta e cinco infelizes. No chão, como WC, um buraco no encanamento do esgoto. Pelas paredes de tábuas, frestas de mais de quatro dedos, têm os velhos e sórdidos seus dormitórios. Pelas camas, em que enxameiam moscas, manchas pretas e fedorentas. E um tênue cobertor para proteger do vento frio e úmido que zune pelas frestas. No dormitório dos doentes velhos é o mesmo quadro. Na seção de furiosos, já que não é possível conserválos vestidos, pelas grandes janelas sem vidraças entra o frio e a chuva espadanante lava todo o pavilhão. (D.N., p. 12)

É mister dizer que as fotos que existem no Diário de Notícias nos dão a exata imagem do que se lê nestes trechos jornalísticos.

O livro de Jacintho prossegue com o capítulo sobre o relato de pessoas ilustres, “Algumas visitas realizadas na época”, entre eles Borges de Medeiros, Belizário Penna (eminente sanitarista e eugenista) e Getúlio Vargas. Referindo-se à visita deste último, em 16 de junho de 1929, relata uma grande entrevista do matutino Correio do Povo, tendo o seguinte título de matéria em "caixa alta” no texto: "O PRESIDENTE DO ESTADO VISITOU ONTEM DEMORADAMENTE O HOSPITAL SÃO PEDRO, QUE PROMETE SER UM DOS MODELARES DO PAÍS” (Godoy, 1955, p. 49), e que termina com a seguinte frase: "O dr. Getúlio Vargas, ao retirar-se do Hospital São Pedro, manifestou ao dr. Jacinto Godoy a excelente impressão que colhera em sua visita, felicitando-o pelas obras de transformação do velho Hospital São Pedro” (ibid., p. 55).

Percebe-se, assim, que sua intenção era idêntica àquela que dominou o "espírito" dos dirigentes do Estado Novo, isto é, o grande desejo de mostrar melhorias, através de obras gigantescas, seja da cidade, seja no hospício. Assim Getúlio, assim Jacintho.

Em algumas páginas de seu livro, Jacintho critica as administrações do hospital anteriores à sua, com a finalidade de justificar suas atuais obras de modernização. Suas "ações travestidas de novidade” como nos fala Wadi, serviam como estratégia "através da qual o discurso do psiquiatra ao criticar internamente um espaço construído por seus pares, quer na verdade apontar mudanças no comportamento da corporação médica, buscando ampliar e diversificar o seu espaço de poder" (Wadi, 2002, p. 212).

Mas ele assumia abertamente suas idéias positivistas, em total sintonia com a presidência do Estado, que certamente contaminaram a maneira como dirigiu o hospital e também os métodos terapêuticos aos quais se filiava. Seus pontos de vista, da política às suas idéias sobre doença mental e psiquiatria, não diferem em absoluto. Era esta sua Weltanschauung.

O longo discurso que proferiu no ato inaugural do Manicômio Judiciário, em 4 de outubro de 1925, está exibido no quarto capítulo de seu livro. Fazendo 


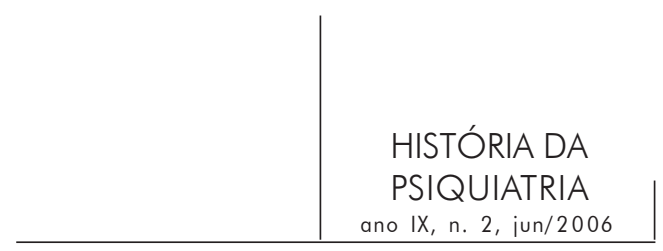

suas as palavras de dois peritos psiquiatras franceses (Dubuisson e Vigouroux), cuja obra conheceu durante sua estadia na França, ele concorda que “o indivíduo não pode e não deve ser punido, senão porque é intimidável, isto é, porque susceptível de ser corrigido pela punição” (Godoy, 1955, p. 67). E logo adiante, justifica: “Não é nem por espírito de vingança, nem com o fim de fazer expiar uma falta, que a sociedade inflige uma pena a um de seus membros. Assim agindo, ela visa exclusivamente um fim, o de se proteger, na esperança de melhorar o culpado e também de ver o castigo servir de exemplo”. Desta forma, a punição seria um "verdadeiro tratamento moral”, que tem por efeito fortalecer a vontade do "culpado", despertando nele, no momento em que está prestes a perturbar a ordem social, um sentimento de temor que o impeça de agir. O tratamento é a coação e não um verdadeiro tratamento psicológico.

A discussão, neste seu longo discurso - ou pelo menos a fala que apresenta escrita em seu livro - é a respeito do criminoso/doente que os peritos devem “tratar”. Todos os homens, para esses peritos, são intimidáveis, com exceção dos alienados [isto procede?], e em face destes, "o papel da sociedade consiste exclusivamente, além de assistência e do tratamento que ela lhes fornece, em proteger-se e impedi-los de fazer o mal” (ibid., p. 67).

Mas não seria a mesma coisa? Pois o alienado também faz o mal, segundo sua acepção.

E, partidário da teoria positivista, ele diz: “A teoria positivista admite que, por injusto que possa parecer à primeira vista, a pena deve ser tanto mais forte quanto o indivíduo mal-nascido, mal-educado, apaixonado, tem necessidade de uma punição mais severa para ser intimidado” (ibid., p. 69).

Mais adiante no mesmo discurso ele revela seu posicionamento sobre a matéria médica que estuda e a qual pratica:

Meus senhores, a psiquiatria não escapou à lei dos três estados: religioso, metafísico e positivo. No estado religioso, completamente divorciado da medicina, o alienado considerado um possesso do demônio é encarcerado nas prisões. A reforma de Pinel inaugura o período metafísico e a psiquiatria ingressa no domínio propriamente médico, mas o caráter essencialmente filantrópico da reforma desse grande homem explica as tendências puramente filosóficas e psicológicas desse estado. É com Morel que começa o estado positivo, verdadeiramente científico, em que a noção da etiologia tóxica ou infecciosa serve de base a uma classificação nosológica. No momento atual da ciência médica, diante das conquistas maravilhosas da Biologia, já se pode afirmar com desassombro que as moléstias mentais não existem. O que existem são síndromes mentais ou afecções cerebrais com expressão psíquica, determinadas por perturbações orgânicas ou funcionais produzidas por toxi-infecções adquiridas ou herdadas (ibid., p. 72-3; grifos meus). 


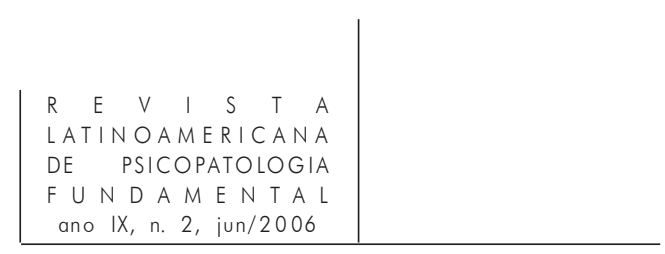

Ainda é importante ressaltar que entre as terapêuticas administradas prevaleciam aquelas que possuíam um efeito orgânico, sendo elas malarioterapia, insulinoterapia, convulsoterapia (por cardiazol, cloreto de amônio e, posteriormente, eletrochoque), penicilinoterapia para pacientes com neuro-sífilis e psicocirurgia (lobotomia). A justificativa, dada por JG em seu livro, estava alicerçada em argumentos humanitários e científicos:

O Hospital São Pedro, apesar de superlotado, não se conformou com a situação de depósito de doentes, para dar apenas assistência do alojamento (...). Procurando desvencilhar-se dos percalços decorrentes do excesso de doentes, conseguiu manter sempre uma organização técnica capaz de executar todas as modalidades terapêuticas em voga nas clínicas estrangeiras. (Ibid., p. 337)

Fica claro, a partir destas reflexões (e da pesquisa realizada), que o discurso de JG - que é uma expressão pura de positivismo aliado à noção de "herança" da corrente eugênica - imprimiu um certo imaginário em nossa sociedade, a respeito do doente mental. ${ }^{4}$ Discurso médico-científico aliado à visão de mundo de quem o propaga, com pitadas de uma personalidade autoritária, justificaram seus métodos e práticas autoritários. E, friso, a concepção organicista da psiquiatria estava, nesse momento, a serviço de ambas vertentes de pensamento.

Embora investisse em técnicas caras e "modernas", o "abnegado" doutor Godoy enfatiza que "aí (no hospício) tudo pode passar - os diagnósticos e as terapêuticas, mas há os que sempre ficam durante toda a existência física, os doentes crônicos e incuráveis, e, a seu lado, os psiquiatras através de sua vida profissional" (ibid., p. 419; grifos meus). Esta afirmação faz parte da "oração" dele mesmo proferida em 1949, quando da inauguração de novos pavilhões no HPSP, um dos quais recebeu seu próprio nome.

Wadi (2002, p. 213), a este respeito, apropriadamente refere que ainda em meados do século XX, "os psiquiatras usam uma espécie de mito de origem para afirmarem-se como os legítimos guardiões da loucura". Sendo homens de competência e abnegados servidores da razão, guiam-se pelo exemplo de seus mestres e constroem discursos que os legitimam como "peritos", tendo representado isto uma significativa vitória da psiquiatria. (Ver Santos, 2005c, p. 94-108).

No discurso de Godoy, o especialista psiquiatra tinha uma missão humanitária, filantrópica, ou seja, dar àqueles que perderam a consciência do

4. Desde a década de 1910-20, a eugenia e seus métodos de "purificação" do ser humano estavam em vigor no Brasil, porém foge à finalidade deste breve artigo adentrar estas questões, tão importantes naquele momento histórico e tão caras aos estudiosos. 


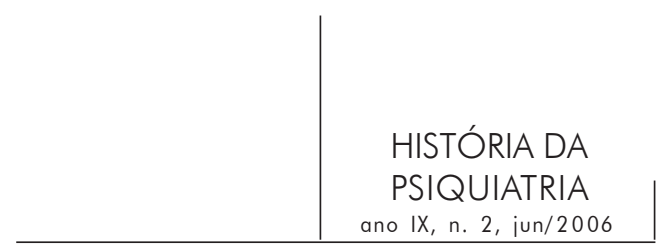

mundo ao soçobrarem nas “trevas da alienação”, a dignidade de um doente comum. Porém, esta assertiva mostra que, "mais do que a defesa ou a proteção destes desvalidos, a tutela dos loucos pelos médicos significava tanto o controle absoluto do espaço institucional quanto a normatização da loucura sob os ditames da psiquiatria” (Wadi, 2002; Wadi \& Santos, 2006).

Há um documento encontrado no HPSP, com depoimentos de pacientes, chamado “Memórias de um velho hospício”, o qual vem de encontro, também, ao que era propalado por esse seu diretor. É um impresso do próprio hospital idealizado e escrito por Rui Carlos Müller, chefe da recreação do hospital, em 1975. Nele constam depoimentos de pacientes que residiam no hospital há décadas, alguns deles bem perto do momento em que JG é exonerado da direção, em 1951. Reproduzo aqui três deles: "Há 28 anos o pátio era brabo, brigaçada todo o dia, era sangue para tudo quanto era lado. A gente pegava a caneca e fincava na cabeça das outras”. "Havia muitas brigas, dormíamos nuas lugares cheios de m... no chão, que além de imundos e fedorentos passávamos frio e só tínhamos um lençol por cima e outro por baixo." "Quem cuidava dos pacientes eram as irmãs (...) a medicação era de uma qualidade só. O choque era direto, ${ }^{5}$ todas deitavam e preparavam a boca, e as primeiras que levantavam já iam ajudando as outras. Hoje apesar de fraca das vistas ajudo na cozinha.”

Parece-me importante, a partir deste momento, tentar repensar o imaginário sobre a loucura sob um outro ponto de vista: não mais desde aquele do saber médico institucionalizado, competente cientificamente para diagnosticá-la e tratála, mas a partir daquele que a sente e a vive. Neste enfoque, teremos as representações que o próprio paciente faz de sua “doença” e de sua experiência de internação. Parto do princípio de que é sua história de vida que deveria ser o ponto de partida para um tratamento adequado e profícuo.

Ao debruçar-me sobre os doentes e seu destino, compreendera que as idéias de perseguição e as alucinações se formam em torno de um núcleo significativo. No fundo, há os dramas de uma vida, de uma esperança, de um desejo. Se não lhes compreendemos o sentido, é uma falha nossa. Nessas circunstâncias, compreendi pela primeira vez que na psicose jaz e se oculta uma psicologia geral da personalidade e nela se encontram todos os eternos incuráveis, obtusos, apáticos, se agita mais vida e sentido do que pensamos. No fundo, não descobrimos no doente mental nada de novo ou de desconhecido; encontramos nele as bases de nossa própria natureza... (Jung, 1984, p. 117-8)

5. Refere-se ao eletrochoque (ECT), prática de tratamento instituída no HPSP pelo dr. Jacintho Godoy, em 1944. 


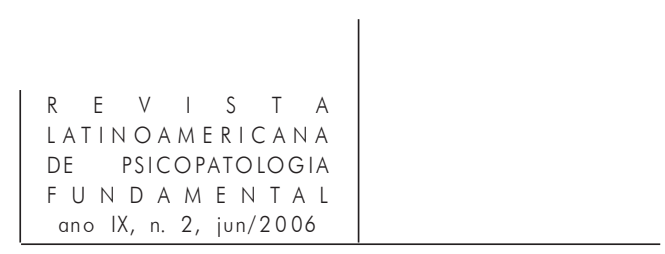

Sob uma perspectiva histórica, problemas específicos demarcaram as práticas de exclusão dos indivíduos tidos como loucos, como por exemplo, o fato de ter sido negado a esses pacientes o papel de sujeitos da história, pois foram estigmatizados em seu convívio social. As representações da loucura que a sociedade fez, nesta prática social de exclusão, foram legitimadas pelo discurso médico oficial ou serviram para legitimar este próprio discurso, tendo, assim, o imaginário da exclusão favorecido, como se viu, a formação de espaços urbanos que privilegiaram o isolamento e o confinamento do doente, criando verdadeiros depósitos de seres humanos, fora de toda a prática social integradora.

A estes "excluídos da história", os loucos, a sociedade negou o papel de cidadãos, privando-os de sua dignidade respeitada, de sua autonomia realizada e seus direitos e deveres exercidos em todas as instâncias individuais e sociais. Como pensar o ser humano "louco" (indivíduo portador de transtorno mental) como cidadão, se as práticas sociais de exclusão imperaram, historicamente, na formação da identidade dessas pessoas? A sua identidade foi privada de sentido social, foi negativa e estigmatizada. Pensar o ser humano cidadão é pensá-lo na relação das forças sociais que instauram a diferença, pois é sendo e sentindo-se um "não diferente" que ele pode ser incluído na sociedade dos "iguais". Cidadania e exclusão são representações da ordem social que orientam práticas e instauram paradigmas sociais (Paugam, 1996) sendo, portanto, conceitos construídos historicamente.

Partindo de uma representação específica de "doença” e, por conseguinte, de “doença mental”, conforme empregada pelo psiquiatra suíço Carl Gustav Jung, argumento que a loucura, ou doença mental, não deve ser entendida como uma patologia estanque, que deva ser critério para exclusão social de um indivíduo. Ela comporta, em si, também elementos criativos, vindos de seu inconsciente que em termos contemporâneos chamamos também de imaginário - os quais podem dar outro rumo a uma vida humana e, portanto, a uma sociedade.

Em meados do ano de 1937, um paciente, aqui denominado por suas iniciais TR, vindo de Canoas e de família de pequenos comerciantes locais - mas que tiveram posses para bancar uma internação particular - foi internado no HPSP com o diagnóstico de parafrenia, nomenclatura, na época, utilizada para designar síndromes de delírio crônico.

Nessa internação de quatro meses (junho a setembro) ele escreveu cartas, doze cartas, as quais foram conservadas arquivadas em seu prontuário médico - para a tristeza dele, pois não foram enviadas, e para o deleite de futuros pesquisadores que agora, como eu, debruçam-se nesta documentação ímpar - e constitui, a meu ver, uma espécie de "diário íntimo" do autor. Consideradas pelos médicos de então delírios e sintomas da doença mental que o afligia, elas são muito mais do que isto, pois revelam confidências e reflexões que mostram tanto 


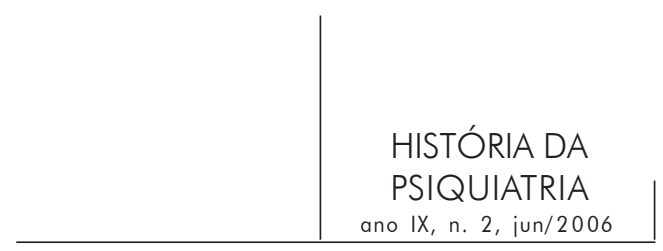

o problema desse indivíduo em particular, como a turbulência pela qual estava passando a humanidade, naquele período histórico. ${ }^{6}$

Ele foi levado ao hospital pela família (pai e irmão) que, entre outras coisas, apontava como causa de seu "enlouquecimento", o fato de TR ler e escrever muito. Ao ser entrevistado no momento da baixa hospitalar, o pai de TR deixou clara a visão que possuía sobre o estado do filho. Ficaram registradas, no prontuário médico, suas impressões, dando início, assim, à constituição de um “núcleo” de representações e de sensibilidades sobre a "loucura de TR", um "homem qualquer”, um anônimo, um "pequeno industrialista, fabricante de sabão contra a caspa”, para usar suas próprias palavras.

Se TR escrevia muito em casa, conforme informou seu pai na admissão ao hospital - e isto era um dos sinais de loucura de seu filho -; no hospital ele continuava a escrever, e muito também, como se tem oportunidade de ver pelas cartas encontradas. Mas para ele isto não era sinal ou sintoma de loucura. É a partir de seu próprio “depoimento”, conferido na carta de número 11, denominada por ele mesmo de "Meditações e previsões sobre o futuro", que se pode ver a importância que isto tem em sua vida:

Disse que escreveria enquanto estou aqui [no hospício] porque em casa não poderei fazê-lo, devido que pai mãe esposa irmãos se anteporem a mim como uns endemoniados por julgarem que estou louco.

Meu pai esteve aqui me visitando no sábado passado. Eu querendo conseguir mais liberdade em casa, disse-lhe em resposta a sua pergunta se já tinha deixado a mania de escrever que se era loucura porque não me deixa esta. Foi quanto bastou para que pouco depois saísse... [re]almente se despediu de mim. Para mim acho que esta contrariedade até é uma vantagem, pois que tenho notado, quando me incomodam, tenho até mais inspiração. É verdade que às

6. Essas cartas, quando foram encontradas em seu prontuário (arquivado no Arquivo Público do Estado do RGS) estavam desordenadas e foram colocadas em uma ordem cronológica conforme apareciam suas datas ou pelo contexto que apresentavam. Após, foram transcritas e digitalizadas. Este "achado” formidável aconteceu durante a referida pesquisa para dissertação de mestrado e originou posteriormente um livro, publicado em 2005 pela editora da UPF (Santos, 2005c), e também uma tese de doutorado (Santos, 2005b), onde dando o estatuto de literatura ao conjunto desta correspondência, comparei-a a outros "escritos de hospício" de literatos que escreveram sobre internações psiquiátricas, o romance simbolista No Hospício, de Rocha Pombo e o romance inacabado do escritor pré-modernista Lima Barreto, Cemitério dos Vivos. Ao conjunto dessas missivas dei o nome de Cartas de Hospício de TR, as quais encontram-se inéditas até o momento para o público mais amplo, existindo em sua íntegra somente como anexo da referida tese de doutorado, depositada atualmente na biblioteca do IFCH da UFRGS. 


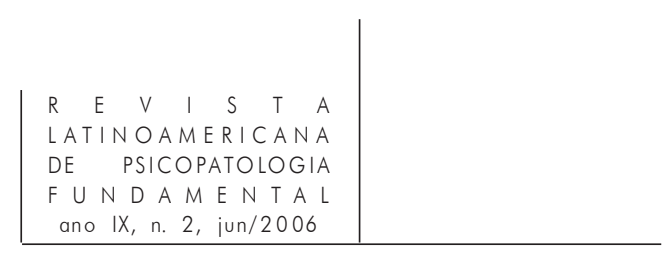

vezes desanimo um pouco e não faltava muito me convencer da minha loucura...

(Carta 11, p. 44)

Convencer TR de sua loucura foi algo que não aconteceu. Mas ele possuía, sim, uma noção sobre sua enfermidade, pois disse: "Tenho esperança de sair completamente curado deste hospital, pois que a meu ver o fator máximo de minha moléstia é o excesso de trabalho físico e intelectual, para meu corpo enfermo, se bem que há outros fatores. Enfim uma causa age sobre a outra resultando o desequilíbrio da saúde” (Carta 11, p. 45).

Não é preciso frisar que essas cartas nunca chegaram a seus destinatários. Embora seu diagnóstico tenha sido “paraphrenia” (parafrenia) o conteúdo dessas cartas talvez menos tenha a ver com “delírios” e muito com a própria história de vida de seu autor. Eram cartas em geral de muitas páginas, escritas na sua maioria em papel almaço, com boa letra e sem rasuras, dirigidas a um "amigo" (Vianna Moog), a editores de jornais, ou eram artigos para a imprensa, desabafos “filosóficos”, bem como outras, direcionadas a "personalidades” de destaque da época como o Arcebispo Metropolitano e o Governador do Estado do Rio Grande do Sul.

Algumas cartas revelam os problemas que teve com o pai e os negócios da família. Outras mostram suas idéias a respeito da religião católica, colocandose como cristão e não católico. Deixa transparecer uma certa admiração pelo nazismo e pela pessoa de Hitler e foi adepto do integralismo e do positivismo. Queria a paz no mundo, embora seu mundo interno não vivesse em paz. Ao mesmo tempo, ele se diz um ex-integralista, refere a si mesmo como um Judas, ou assemelha-se a Deus, e briga com a Igreja Católica e seus padres (Santos, 2005b). Ama e odeia ao mesmo tempo: “Apaixonado por vós, vos odeio, porque pregais na igreja o cúmulo da imperfeição-perfeita” (Carta 3). ${ }^{7}$

Opto sempre por frisar que não faço “julgamento de valor” sobre suas opiniões. Importa constatar que, para mim, elas não representam tão simples e necessariamente “idéias delirantes”, pois retratam uma realidade, tanto interna (psicológica), quanto externa a ele próprio.

Sua bela narrativa, entre oxímoros e metáforas, que compõe o conjunto dessas missivas, expõe muito de sua situação de vida, da situação em que se encontra na internação psiquiátrica, a reflexão sobre a medicina do momento, de sua cultura, tudo arrematado pelo belíssimo português em que escreve - não só no sentido formal da língua, mas principalmente pelas situações simbólicas que descreve. Tudo isto faz com que se afirme de antemão: sua individualidade é ímpar e não há quem não se interesse em ler suas cartas. Significa também

\section{Esta carta foi endereçada ao Arcebispo Metropolitano Dom João Becker.}


que não há diagnóstico que se possa fazer que consiga descrever toda a complexidade de uma personalidade. Antes pelo contrário: os diagnósticos nunca fazem justiça ao que realmente a pessoa sente e pensa sobre si e o mundo.

Sua correspondência de hospício, que quando transcrita e digitada somou 48 páginas, exemplifica de forma contundente o entorno físico de um paciente internado, as más condições das instalações em que foi colocado, a precariedade das relações humanas dentro de um hospício. As cartas que o paciente escreveu, durante sua internação, permitem que possamos traçar um retrato tanto do imaginário pessoal quanto do imaginário coletivo, isto é, mostram aspectos de uma época, de uma cidade, de um país e de um mundo conturbado com guerras e ascensão de regimes totalitários.

Assim, TR recuperou várias discussões, internas e externas à psiquiatra de seu momento histórico, bem como construiu, desde dentro de seus delírios imagens simbólicas de conteúdos que vinham do inconsciente - uma visão própria sobre sua loucura.

É importante, também, ressaltar que algumas cartas são depoimentos desesperados de quem está sofrendo e passando por uma internação psiquiátrica, tendo contato com a realidade diária e aviltante de um hospício. Alguns pequenos trechos demonstram isto: "a todo instante sou interrompido por loucos que, ora me pedem cigarro, ora fogo, ora a pena. Para dizer-vos basta que estou escrevendo encostado da latrina e de cigarro na boca ..." (Carta 3); "ando seboso, quando vão me tirar daqui?”; “aqui no hospital começo a ver fantasmas...” (Carta 4).

Com freqüência, ele deixa transparecer em seus desabafos a indignação sobre a falta de condições, lá dentro mesmo do hospital, de receber um pouco de papel para escrever, logo ele que queria ser escritor: “... aqui nem a muque dão-me papel; Regime de hospital ...” (Carta 9); "rogo desculpar-me o feitio desta que é cara como tudo, aqui no hospital, onde estou e tenho que lutar com sérias dificuldades para adquirir um pouco de papel e tinta na altura, pois crêem que sou maníaco" (Carta 7).

Porém, não deixa de admitir, em outros momentos, que está doente e precisa de tratamento (Carta 6), quando diz, com ironia: “... atestando o meu estado de hiper-excitação nervosa, que claramente transparece naqueles versinhos rudes, pelo fato de reviver dias amargos e estar atualmente adoentado e em tratamento achando-me sob o açoite da medicina que desequilibra para equilibrar...”.

TR escrevia para Vianna Moog (VM), e toma emprestado a este o expediente de suas "Cartas Persas", que Vianna publicava no periódico Correio do Povo, nesse ano de 1937. Essas crônicas jornalísticas de VM em forma de cartas, e que depois originaram um livro, remontam a Montesquieu; e em ambos autores serviam para satirizar a situação político-social pela qual seus países estavam passando (França e Brasil, respectivamente). Pois o que TR faz é servir- 


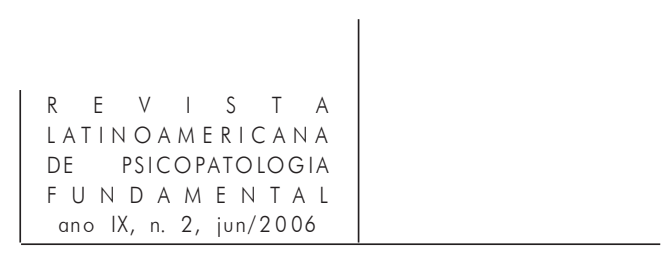

se do mesmo expediente literário para criticar o hospício, a medicina e as agruras que enfrenta dentro e fora do hospício (pelos padres da igreja, por sua família e sociedade como um todo). Eu diria que ele chegou a fazer "crônicas de hospício", em algumas dessas missivas.

Ao contrário do que preconizavam muitos de seus contemporâneos médicos, doença, para ele, parecia estar de acordo com os preceitos de Jung, isto é, ela é um desequilíbrio que, momentâneo, possui uma finalidade, a de voltar a equilibrar a psique. Encara-se, portanto, a perda de equilíbrio como algo adequado, pois substitui uma consciência falha pela atividade automática e instintiva do inconsciente que sempre visa a criação de um novo equilíbrio. Assim TR, assim Jung.

Fazendo um exercício da imaginação e tentando ver TR "por ele mesmo", a partir de seus escritos, diríamos que ele era um homem que gostava muito de ler e escrever (Carta 4), e conhecia vários autores, em profundidade, embora paradoxalmente negue isto em seguida (Carta 9). Era trabalhador desde muito jovem (Carta 11) e sentiu-se injustiçado quando o pai tirou-o da sociedade da família, colocando seu irmão mais jovem em seu lugar. Teve um grande amor em sua vida que foi frustrado em sua realização mais plena (Carta 9). Casou-se, após inúmeras aventuras amorosas, com uma moça de "família" e teve dois filhos, sendo que sua primogênita morreu ainda bebê (Carta 4), o que lhe deixou um profundo sentimento de desamparo.

Era um homem que refletia sobre os assuntos contemporâneos, foi adepto do integralismo e da "ciência positivista" (Cartas 2, 3, 10 e 11). Tinha idéias bem definidas sobre os padres da Igreja Católica e o Clero (várias cartas). Era um "homem da capital” (Carta 3), embora residisse na região metropolitana (Carta 8). Lia alguns filósofos, bem como conhecia alguns clássicos da literatura mundial (Cartas 2, 3, 4 e 9). Bem informado sobre o que acontecia pelo mundo, lia jornais de Porto Alegre e Alemanha (Cartas 1, 2 e 3) e posicionava-se em relação a discursos de líderes políticos e acontecimentos europeus, como a Guerra da Espanha, que transcorria naquele momento (em quase todas as cartas) e o nazismo.

Porém, o tom ressentido de todas as suas cartas denota que havia um segredo escondido e este ele talvez não pudesse admitir explicitamente, não pudesse revelar nem para si próprio. Pois era seu segredo pessoal, o qual aparece metaforicamente já na primeira carta como um "veneno em sua alma”...

Estou mais ou menos a par do momento político que vive o Brasil, terra que ora visitas, também conheço perfeitamente o eixo político que criou uma verdadeira confusão de idéias, que não é exagero dizer, em todos países do universo. Caro amigo, sinto e lastimo imensamente que o Brasil não queira se orientar pelo livro mais sagrado de nossa terra e de todo mundo, que foi escrito 
com o próprio sangue do grande profeta que morreu pregado na cruz de Gólgota, cuja vida foi ensinar a cada habitante deste mísero planeta o que mais nobre e belo o homem, uma consciência sã de que nasceu para ser feliz e perfeito. Liberdade doce liberdade, liberta-nos do jugo estrangeiro e de nós próprios ... Quem é que nos pode libertar do jugo estrangeiro e de nós mesmos? A Igreja!... por que já não o fez?... (Carta 1, p. 20)

Existe, porém, uma carta escrita em alemão e endereçada a Hitler, onde consta uma confissão de fatos acontecidos a ele no passado: foi seduzido por um padre da igreja, este é o seu segredo. Ele utiliza a carta para confessar seu "pecado", não o confessando, pois esta parte, e somente esta, ele escreve em alemão. "A carta pessoal 'diz' que o segredo existe, explicitando seus limites, ou faz crer que ele não existe e que a confissão é plena” (Gomes, 2004, p. 21).

E buscando referência novamente no psiquiatra suíço:

Em muitos casos psiquiátricos, o doente tem uma história que não é contada e que, em geral, ninguém conhece. Para mim, a verdadeira terapia só começa depois de examinada a história pessoal. Esta representa o segredo do paciente, segredo que o desesperou. Ao mesmo tempo, encerra a chave do tratamento. É, pois, indispensável que o médico saiba descobri-la. Ele deve propor perguntas que digam respeito ao homem em sua totalidade e não se limitar apenas aos sintomas. Na maioria dos casos, não é suficiente explorar o material consciente... (Jung, 1984, p. 44)

Existem duas versões desta carta, como se uma (Carta 5) fosse o rascunho e a outra aquela que deveria ser enviada (Carta 4). Na primeira consta a confissão, na segunda não. Chegou-se a esta conclusão, pois a quarta carta está escrita em português até o final, onde então aparece o trecho alemão - somente sem as frases que fazem o ato confessionário - exatamente igual ao outro trecho alemão, o qual está isolado em um outro pedaço de papel. Comparando com as outras cartas, em português, encontra-se nestas, em alemão, conteúdos que vão além, em termos de subjetividade, deixando uma pergunta no ar: por que exatamente esta, e somente esta, foi escrita em alemão?

A seguinte passagem da carta é aquela que falta na Carta 4 e existe na de número 5. Coloco-a com a respectiva tradução na lateral: ${ }^{8}$

Geb’ Er mir nen Pfaffen aus (ans) Papier

Nen’ Gummi dran das auf der Brust

Der Pfaffe bammeln kann nach lust.

Dat will i haben weiter nischt.
Me livre ele dos padres de papel Da borracha sobre o peito O padre "copula" quando quer Isto eu quero ter, nada mais. 


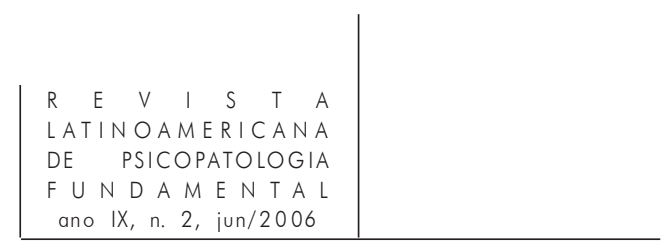

Schade das die G'schicht schon aus ist. Ehr"werden können Sie mich verzeihen? Mich verführt haben die Pfaffenschafte. Was hätte ich getan?

Wenn ich zur letzten Stunde Gott hätte gesagt

tu es nicht du bist auf falschen weg geraten. Ich Hochwürden wollen gnädigst mir einen Beichvater senden, werde alles beichten, habe jetzt noch etwas bange, aber vielleicht tue ich es schriftlich, / ich glaube

es wäre besser denn so hätte die Kirche / documente um Ihre feinde niederzerschmettern. Warte / para aniquilar (esmagar) os Seus /

Assim, essa carta, que ele mesmo denominou de “A confissão”, é de fundamental importância para trabalharmos a história pessoal de TR, pois o simbolismo que nela aparece revelam toda a "trama” que sua vida teceu, até desembocar na "loucura”, na sua dissociação psíquica. Foi um drama não compreendido, de um homem que manteve relações íntimas com um padre, numa relação de amor e ódio, à imagem e semelhança da película de Almodóvar (A má educação). Esta carta apresenta a história psicológica de TR que a medicina da época, com seus postulados organicistas e “moralizantes”, não enxergou.

Depois deste “desabafo” no papel, suas cartas retornam ao tom menos metafórico e são escritas em uma linguagem mais direta e "racional”.

É digno de nota, ainda, o que lemos na Carta 11, onde ele escreve sobre a importância da escrita em sua vida, e a finaliza expressando algo que talvez os médicos tivessem gostado de ouvir, naquele momento, e quem sabe não tenha escrito sabendo que eles o leriam:

Mas o meu grande amigo é o futuro e eu confio plenamente nele. Tenho esperança de sair completamente curado deste hospital pois que a meu ver o fator máximo de minha moléstia é o excesso de trabalho físico e intelectual, para meu corpo enfermo, se bem que há outros fatores. Enfim uma causa age sobre a outra resultando o desequilíbrio da saúde. Terei errado dizendo tudo isso? Pouco já me importa. Tive que desabafar uma vez o que me ia no íntimo, mesmo que isso seja erro. O meu estado de saúde tem melhorado muito graças a atuação por parte dos cientistas inclusive o diretor deste hospital e quando me lembro da possibilidade de minha completa cura, tenho vontade de ficar mais um ou dois anos, não obstante ter muita saudade de esposa e filho que vejo uma vez por semana. 


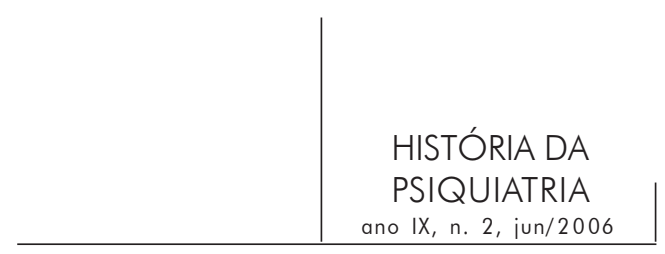

TR demonstrava uma vivacidade, um otimismo e um senso de humor raros e que permite que façamos uma aproximação explícita com os escritos de Vianna Moog (das Cartas Persas) e de Lima Barreto (dos Bruzundangas). Ele tentou, através das "narrativas da loucura” expressar sua dor e suas idéias, mas também possuía talento para transformar toda esta matéria-prima em literatura. Desta forma, afirmo que suas potencialidades foram dizimadas pelo imaginário de uma época, pela opção de “ciência” que vigia no hospital em que foi internado e pelas representações da loucura que sua família tinha.

Enquanto JG preconizava o tratamento moral e a "intimidabilidade" dos “desviantes crônicos” (Godoy, 1955, p. 66) - e TR devia ser um deles, pois estava escrito em seu prontuário “alta sem cura” - TR sentia-se sob “o açoite da medicina que desequilibra para equilibrar” (Carta 6).

Nunca é demais ressaltar que, no período histórico abrangido por este estudo, o “pai” da psicanálise já estava morrendo (Freud faleceu em 1939) e a teoria de Jung (morto somente em 1961) já era aplicada no Brasil (na década de 1940) pela dra. Nise da Silveira, no Hospício de Engenho de Dentro, do Rio de Janeiro.

Muito mais poderia ser dito, mas eu quis ressaltar aqui a importância de atentarmos para outras fontes a fim de resgatar a história da Medicina e da Psiquiatria no Brasil. E, também, participo da idéia de que outros olhares e outras práticas sobre o doente mental são possíveis, desde que se mude o paradigma sobre doença mental.

\section{Referências}

Artières, Philippe. Clinique de l'écriture: une histoire du regard médical sur l'écriture. Paris: Institut Synthélabo, 1998.

Chartier, Roger. O mundo como representação. Estudos Avançados, v. 5, n. 11, p. 183, 1991.

Godoy, Jacintho. A psiquiatria no Rio Grande do Sul. Porto Alegre: edição do autor, 1955.

Gomes, Ângela de Castro. Escrita de si, escrita da história. Rio de Janeiro: FGV, 2004. Jung, C. G. Memórias, sonhos e reflexões. Rio de Janeiro: Nova Fronteira, 1984.

Paugam, Serge (org.). L'exclusion, l'état de savoirs. Paris: Éditions la Découverte, 1996. Pesavento, Sandra. Fronteiras da ficção - diálogos da História e da Literatura. Revista de História das Idéias, Coimbra: Faculdade de Letras, v. 21, 2000.

SAnTos, Nádia Maria Weber. Escritos de si como reveladores de sensibilidades sobre 


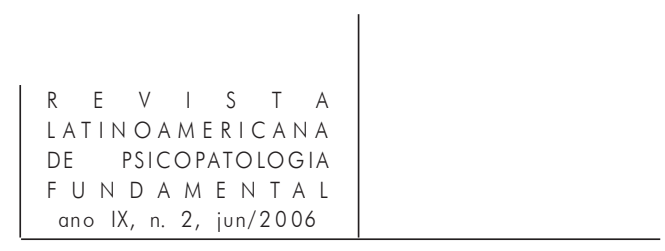

a loucura (Brasil, início do século XX). Colóquio. Nuevo Mundo Mundos Nuevos, n. 5, março de 2005. <http://nuevomundo.revues.org/document837.html>. Acesso em: 15 de abril de 2006. (2005a)

Histórias de sensibilidades - espaços e narrativas da loucura em três tempos (Brasil, 1905/1920/1937). 2005. Tese (doutorado em História). Universidade Federal do Rio Grande do Sul. (2005b).

Histórias de vidas ausentes - a tênue fronteira entre a saúde e a doença mental. Passo Fundo: Editora UPF, 2005c.

WADI, Yonissa Marmitt. Louca pela vida: a história de Pierina. 2002. Tese (doutorado em História Social). Pontifícia Universidade Católica de São Paulo. (2002a).

Palácio para guardar doidos - uma história das lutas para a construção do hospício de alienados e da psiquiatria no RS. Porto Alegre: Editora da Universidade UFRGS, 2002b.

WADI, Yonissa Marmitt \& SAntos, Nádia Maria Weber. O doutor Jacintho Godoy e a história da psiquiatria no Rio Grande do Sul/Brasil. Nuevo Mundo Mundos Nuevos, n. 6, janeiro de 2006. <http://nuevomundo.revues.org/document1556.html>. Acesso em: 15 de abril de 2006.

\section{Resumos}

Este artículo presenta aspectos de dos discursos, concernientes a la sensibilidad sobre la locura, en representaciones (narrativas) escritas por un médico y un paciente, ambos del Hospital Psiquiátrico São Pedro de Porto Alegre, inseridos en los años del 20 al 50 de siglo XX, en Río Grande do Sul. Para ello, se utilizo el libro de Jacinto Godoy, A psiquiatria no Río Grande do Sul, publicado por el autor en 1955, y las cartas de un paciente internado en 1937, archivadas en su prontuario médico.

Palabras claves: Locura, psiquiatría, historia cultural, Rio Grande do Sul, narrativa

Cet article presente dês aspects de deux "discours", concernants à la sensibilité à propos de la folie, par de représentations (narratives) écrites par um médecin et un pacient, tous lês deux de l'Hôpital Psychiatrique São Pedro de Porto Alegre, faites dés les années 20 jusqu'aux 50 de XXeme siècle, au Rio Grande do Sul. Pour ce propos, on a utilisé lê livre de Jacintho Godoy. La Psychiatrie au Rio Grande do Sul, publié par l'auteur em 1955, et lês lettres d'um pacient interne, em 1937, archivées dans son historique medical.

Mots clés: Folie, psychiatrie, cultural historique, Rio Grande do Sul, narrative 
HISTÓRIA DA

PSIQUIATRIA

ano IX, n. 2, jun/2006

This article brings up aspects of two “discourses" related to sensitivity toward madness. They consist of representations (narratives) written from the 1920s to the 1950s betweem a physician and a patient, both of the São Pedro Psychiatric Hospital in Porto Alegre, state of Rio Grande do Sul, Brazil. For this purpose, use was made of the book by Jacintho Godoy entitled Psiquiatria no Rio Grande do Sul (Psychiatry in Rio Grande do Sul), published by the author in 1955, and letters from a hospitalized patient, in 1937, taken from his medical records.

Key words: Madness, psychiatry, cultural history, Rio Grande do Sul, narrative 